\title{
WRITING UNEMPLOYMENT
}

Worklessness, Mobility, and Citizenship in

Twentieth-Century Canadian Literatures 
This page intentionally left blank 


\section{Writing Unemployment}

Worklessness, Mobility, and Citizenship

in Twentieth-Century Canadian

Literatures

\section{JODY MASON}

UNIVERSITY OF TORONTO PRESS

Toronto Buffalo London 
University of Toronto Press 2013

Toronto Buffalo London

www.utppublishing.com

Printed in Canada

ISBN 978-1-4426-4433-5

(6)

Printed on acid-free, ${ }_{100} \%$ post-consumer recycled paper with vegetable-based inks.

\section{Library and Archives Canada Cataloguing in Publication}

Mason, Jody, 1976-

Writing unemployment : worklessness, mobility, and citizenship in twentieth-century Canadian literatures / Jody Mason.

Includes bibliographical references and index.

ISBN 978-1-4426-4433-5

1. Canadian literature - 20th century - History and criticism. 2. Unemployment Canada - History - 2oth century. 3. Liberalism - Canada - History - 2oth century. 4. Unemployment - Political aspects - Canada. 5. Working class - Canada - Social conditions. 6. Unemployment in literature. 7. Liberalism in literature.

8. Working class in literature. I. Title.

Ps8101.U46M37 2013 C810.9'3553 C2013-900503-X

University of Toronto Press acknowledges the financial assistance to its publishing program of the Canada Council for the Arts and the Ontario Arts Council.

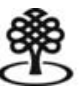

Canada Council for the Arts

\section{Conseil des Arts} du Canada

\section{A ONraAl aris counch

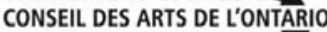

SO ANS DE SOUTES DU GOUYERSEUEST DE L'ONTARIO MUX ARTS

This book has been published with the help of a grant from the Canadian Federation for the Humanities and Social Sciences, through the Awards to Scholarly Publications Program, using funds provided by the Social Sciences and Humanities Research Council of Canada.

University of Toronto Press acknowledges the financial support of the Government of Canada through the Canada Book Fund for its publishing activities. 